\title{
85 歳以上超高齢者に対する心臓大血管手術の検討
}

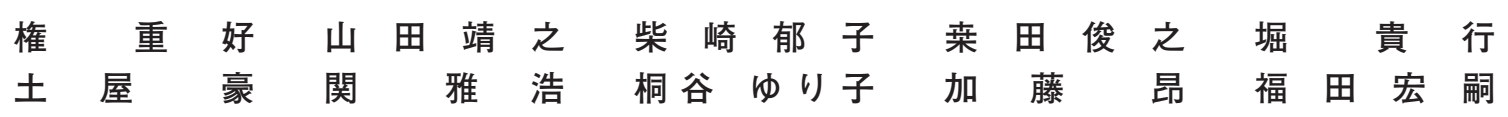

[背景］高齢化社会に伴い，心臟大血管手術患者の適応年齢が拡大している. [対象] 今回われわれは 85 歳 以上の超高齢者に対する心臟大血管手術を経験し，治療方針の妥当性を検討した。 2008 年 6 月から 2012 年 12 月までに当センターで施行した心臓大血管手術 1,026 例中, 85 歳以上の 39 例（3.8\%）を対象とし，待機 手術症例と緊急手術症例を比較検討した。 また, 84 歳以下の対象群と術後経過を比較検討した。平均年齢 $86.3 \pm 1.3$ 歳 (85 90 歳), 男女比 $10: 29$, 緊急症例 19 例 (46.2\%). 施行手術は弓部全置換術 4 例, 上行置 換術 4 例，下行置換術 1 例，大動脈弁置換術（AVR）13 例，僧帽弁置換術 1 例，僧帽弁形成術 2 例，冠動 脈バイパス術（CABG）9 例，AVR+CABG 4 例，腫瘍摘出術 1 例であった。手術時間は 305.8 1113.8 分, 人工心肺時間は $155.6 \pm 64.7$ 分，平均 ICU 滞在日数 3.82 日，術後平均在院日数 41.3 日であった。 [結果］術 後 30 日死亡は 1 例 $(2.6 \%)$, 入院死亡は 6 例 $(12.8 \%)$ であった。手術関連死亡は胸部大動脈瘤破裂に対す る下行置換術の出血死，AVR 後の非閉塞性腸間膜動脈虚血（NOMI）による消化管穿孔の 2 症例であり, その他は経過中に発症した急性心筋梗塞, 肺がん化学療法中に急性大動脈解離を発症し術後脳転移による脳 梗塞, 胆のう炎による消化管穿孔，タコつぼ型心筋症既往の心不全により失った．緊急手術症例群の術後挿 管時間 (89.9 時間 vs. 8.2 時間, $p=0.006)$, ICU 滞在期間 (6.74 日 vs. 1.05 日, $p=0.002)$, 術後入院日数 (58.9 日 vs. 27.5 日, $p=0.049)$ は待機手術症例群と比べ有意に延長した。高齢者の待機手術症例では, 84 歳以下の対象者群と比べ, 在院死亡率 $(2.6 \%$ vs. $5.0 \%, p=0.52)$, 術後在院日数 $(26.7$ 日 vs. 27.5 日, $p=0.54)$ などの術後経過に有意な差は認めなかった。高齢者の緊急手術症例は, 84 歳以下の対象群と比べ 術後在院日数が有意に延長し (58.9 日 vs. 39.1 日, $p=0.03)$, 在院死亡率も高かった $(26.3 \%$ vs. $10.5 \%$, $p=0.004) .85$ 歳以上超高齢者の心臓大血管手術は手術成績，術後経過ともにおおむね良好であり，とくに 待機手術症例においては若年者と同等な手術成績が見込める. [結語] 高齢を理由に手術不適応と判断する のは早計であり, 患者の frailty や精神状態，病態の深刻性，患者家族の意思を考慮したうえで手術適応を 判断すべきである. 日心外会誌 43 巻 4 号：170-176（2014）

キーワード： 85 歳以上；高齢者；心臟大血管手術

Cardiovascular Surgery in Patients 85 or Older

Shigeyoshi Gon, Yasuyuki Yamada, Ikuko Shibasaki, Toshiyuki Kuwata, Takayuki Hori, Go Tsuchiya, Masahiro Seki, Yuriko Kiriya, Takashi Kato and Hirotsugu Fukuda (Dokkyo Medical University Hospital, Heart Center, Cardiac and Vascular Surgery, Tochigi, Japan)

Background : This study was performed to evaluate surgical outcomes after cardiovascular surgery (including urgent surgery) in patients 85 or older. Methods : A retrospective analysis was performed on 39 patients (mean age, 86.3 years ; age range, $85-90$ years) who underwent total arch replacement $(n=4)$, ascending aorta replacement $(n=4)$, descending aorta replacement $(n=1)$, aortic valve replacement (AVR; $n=13)$, mitral valve replacement or valvuloplasty $(n=3)$, coronary artery bypass grafting $(\mathrm{CABG} ; n=9), \mathrm{CABG}+\mathrm{AVR}(n=4)$, tumor resection $(n=1)$ between June 2008 and December 2012 at Dokkyo Medical University Hospital. Results : Six hospital deaths occurred. One patient died due to bleeding from a ruptured descending thoracic aortic aneurysm, and another patient died due to gastrointestinal perforation from non-occlusive mesenteric ischemia (NOMI) after urgent AVR. The other deaths were related to various complications, including lung cancer, cholecystitis, myocardial infarction, and Takotsubo cardiomyopathy, during the postoperative period. Overall 30-day mortality was $2.6 \%$, hospital mortality was $12.8 \%$, duration of hospital stay after surgery was 41.3 days, duration of intensive care unit (ICU) stay was 3.8 days and ventilator time was $49.1 \mathrm{~h}$. Twenty patients underwent elective surgery, and 19 patients underwent urgent surgery. The two groups had similar preoperative characteristics, except for the number of patients with aortic disease. No significant

2013 年 6 月 27 日受付, 2014 年 3 月 9 日採用

Corresponding author : Shigeyoshi Gon

Dokkyo Medical University Hospital, Heart Center, Cardiac and

Vascular Surgery, Tochigi, Japan

E-mail : gon-s@dokkyomed.ac.jp

獨協医科大学病院ハートセンター心臓・血管外科

干 321-0293 栃木県下都賀郡壬生町北小林 880
本研究において一切の利益相反や研究資金の提供はない. None of the authors of this manuscript has any financial or personal relationship with other people or organizations that could inappropriately influence their work. 
difference was evident in hospital mortality $(26.3 \%$ vs. $5 \%, p=0.065)$ or 30 -day mortality ( $0 \%$ vs. $5.3 \%$, $p=0.3$ ) when comparing the two groups. However, the duration of hospital stay (58.9 days vs. 27.5 days, $p=0.049$ ), ICU stay (6.74 days vs. 1.05 days, $p=0.002)$ and ventilator time $(89.9 \mathrm{~h}$ vs. $8.2 \mathrm{~h}$, $p=0.006$ ) was significantly longer in the urgent surgery group than in the elective surgery group. Fourteen patients $(70 \%)$ in the elective surgery group and four patients $(21.1 \%)$ in the urgent surgery group were able to be discharged from the hospital to their homes within 30 days after surgery. These data demonstrated that cardiovascular surgery in patients 85 years of age or older was associated with satisfactory outcomes, and outcomes associated with elective surgery were even better than those associated with urgent surgery. Conclusions:Therefore, advanced age does not represent a contraindication of conventional cardiovascular surgery. Rather, the decision for surgery should take the patient's preoperative condition, the severity of concurrent medical disease, the wishes of the patient, and the predicted functional outcomes into account. Jpn. J. Cardiovasc. Surg. 43 : 170-176 (2014)

Keywords : 85 years old ; elderly patient ; cardiovascular surgery

\section{はじめに}

高齢化社会が急速にすすみ高齢者に対する心臟大血管手 術の適応も拡大している. 平成 23 年度の本邦に打ける 80 歳時平均余命は男性 8.39 歳, 女性 11.36 歳であり, 80 歳 以上でも自立した生活を送り積極的な社会活動をおくる高 齢者が増えている．高齢を理由に手術不適応と判断される ことは早計であり, 手術侵襲や周術期合併症のリスクなど を考慮し, 患者の身体的虚弱性（frailty）や認知症の有無, 手術によりもたらされる日常生活動作（activities of daily living; $\mathrm{ADL)}$ の改善や生活の質（quality of life; QOL)の 向上が得られるか考慮したうえで総合的に判断しなければ ならない，当センターでは高齢者に対して積極的に心臟大 血管手術を行っているが，ときに長期臥床による ADLの 低下や，予期せぬ合併症などにより満足する結果が得られ ない場合がある．今回われわれは 85 歳以上の超高齢者に 対する心臟大血管手術を経験し，治療方針の妥当性を検討 した。

\section{対象と方法}

2008 年 6 月から 2012 年 12 月までに当センターで施行 した心蔵大血管手術 1,026 例中， 85 歳以上の 39 例（3.8\%) を対象とし, 待機手術症例と緊急手術症例を比較検討し た。また, 84 歳以下の対象群と術後経過を比較検討した。 胸部大動脈瘤に対するステントグラフト治療 (TEVAR) は除外した。当センターでの冠動脈バイパス術 (CABG) は心停止下での conventional CABG を基本術式としてい る. 大動脈石灰化により遮断困難な場合は on pump beating CABG，off-pump CABG を選択している. 結果につい ては平均土標準偏差で記載し, 比較検討には Student's $t$ 検定打よび $\chi^{2}$ 検定を用い, 有意水準 $p<0.05$ を統計学的 有意とした。

\section{結果}

平均年齢 $86.3 \pm 1.3$ 歳 (85 90 歳), 男女比 $10: 29$, 緊 急症例 19 例 $(46.2 \%)$ 。危険因子は喫煙 6 例 $(15.4 \%)$, 糖 尿病 5 例 $(12.8 \%)$ ，高血圧 34 例 $(87.2 \%)$ ，脂質異常症 11 例 $(28.2 \%)$, 脳血管障害の既往 5 例 $(12.8 \%)$ であり, 術 前平均 Cre は $1.13 \pm 1.1 \mathrm{~g} / \mathrm{d} 1$ であった。術前診断は胸部大 動脈瘤（TAA） 1 例, TAA 破裂 3 例, 急性大動脈解離 (AAD) 5 例，大動脈弁狭窄症（AS） 12 例，大動脈弁閉鎖 不全症 (AR) 1 例, 僧帽弁閉鎖不全症 (MR) 3 例, 冠動 脈疾患 (CAD) 9 例, $\mathrm{AS}+\mathrm{CAD} 4$ 例, 心㵴腫瘍 1 例であっ た。 AAD，TAA 破裂はすべて緊急手術であるため，必然 的に緊急手術症例に大血管症例が多かった（1/20 vs. 8/ $19, p=0.006)$. しかし, 各疾患では緊急手術症例群, 待 機手術症例群間に統計学的な有意な差は認めなかった。患 者の術前背景を Table 1 に示す。

施行手術は弓部全置換術 4 例, 上行置換術 4 例, 下行置 換術 1 例, 大動脈弁置換術（AVR） 13 例，僧帽弁置換術 (MVR) 1 例, 僧帽弁形成術 (MVP) 2 例, CABG 9 例, $\mathrm{AVR}+\mathrm{CABG} 4$ 例, 腫瘍摘出術 1 例であった (Table 2). 手術時間は $305.8 \pm 113.8$ 分，人工心肺時間は $155.6 \pm 64.7$ であった。手術時間（340.9 136.4 分vs. $272.6 \pm 81$ 分， $p=0.03)$ と人工心肺時間 $(174.4 \pm 82.9$ 分 vs. $136.7 \pm 35$ 分, $p=0.04$ ）は緊急手術症例に打いて有意に延長した (Table 3).

平均 ICU 滞在日数 3.82 日, 術後平均在院日数 41.3 日で あった。術後挿管時間（89.9 \pm 133.9 時間 vs. $8.2 \pm 3.7$ 時 間, $p=0.006)$, ICU 滞在期間 $(6.74 \pm 8.5$ 日 vs. $1.05 \pm 0.2$ 日, $p=0.002)$, 術後入院日数 $(58.9 \pm 68$ 日 vs. $27.5 \pm 45.3$ 日, $p=0.049 ）$ が緊急手術症例群において有意に延長した (Table 3)。緊急手術症例群では大血管症例が多く，それ を除いた両群間でも検討を行った。手術時間 $262.1 \pm 55.7$ 分 vs. $266.4 \pm 78.2$ 分 $(p=0.56)$, 人工心肺時間 $123.2 \pm$ 39.4 分 vs. $132.8 \pm 31.7$ 分 $(p=0.75)$, 死亡率も $9.1 \%$ vs. 
Table 1 Patient's profiles and diagnosis

\begin{tabular}{lccc}
\hline & $\begin{array}{c}\text { Total } \\
(n=39)\end{array}$ & $\begin{array}{c}\text { Elective } \\
(n=20)\end{array}$ & $\begin{array}{c}\text { Urgent } \\
(n=19)\end{array}$ \\
\hline Age (years) & $86.3 \pm 1.3$ & $86.2 \pm 1.4$ & $86.4 \pm 1.3$ \\
Male & $10(25.6 \%)$ & $4(20 \%)$ & $6(31.6 \%)$ \\
Risk factors & & & \\
$\quad$ Smoking & $6(15.4 \%)$ & $2(10 \%)$ & $4(21.1 \%)$ \\
Diabetes & $5(12.8 \%)$ & $3(15 \%)$ & $2(10.5 \%)$ \\
Hypertension & $34(87.2 \%)$ & $17(85 \%)$ & $16(84.2 \%)$ \\
Hyperlipidemia & $11(28.2 \%)$ & $6(30 \%)$ & $5(26.3 \%)$ \\
Cerebrovascular disease & $5(12.8 \%)$ & $1(5 \%)$ & $4(21.1 \%)$ \\
Creatinine (mg/dl) & $1.13 \pm 1.1$ & $1.23 \pm 1.6$ & $1.03 \pm 0.3$ \\
Diagnosis & & & \\
TAA & 1 & 1 & 0 \\
TAA rupture & 3 & 0 & 3 \\
AAD & 5 & 0 & 5 \\
AS & 12 & 9 & 3 \\
AR & 1 & 1 & 0 \\
MR & 3 & 2 & 1 \\
CAD & 9 & 5 & 4 \\
CAD AS & 4 & 2 & 2 \\
Tumor & 1 & 0 & 1 \\
\hline Ur & 3 & & \\
\hline
\end{tabular}

Urgent group had significantly greater number of aortic disease. There were no significant differences in baseline characteristics between elective group and urgent group. TAA, thoracic aortic aneurysm; AAD, acute aortic dissection; AS, aortic valve stenosis ; $\mathrm{AR}$, aortic valve regurgitation; $\mathrm{MR}$, mitral valve regurgitation ; $\mathrm{CAD}$, coronary artery disease.

Table 2 Operation procedures

\begin{tabular}{lccc}
\hline & $\begin{array}{c}\text { Total } \\
(n=39)\end{array}$ & $\begin{array}{c}\text { Elective } \\
(n=20)\end{array}$ & $\begin{array}{c}\text { Urgent } \\
(n=19)\end{array}$ \\
\hline Main procedure & & & \\
Total arch replacement & 4 & 1 & 3 \\
Ascending aorta replacement & 4 & 0 & 4 \\
Descending aorta replacement & 1 & 0 & 1 \\
AVR & 13 & 10 & 3 \\
MVR & 1 & 1 & 0 \\
MVP & 2 & 1 & 1 \\
CABG & 9 & 5 & 4 \\
Conventional CABG & 5 & 3 & 2 \\
Off-pump CABG & 3 & 2 & 1 \\
On-pump beating CABG & 1 & 0 & 1 \\
CABG+AVR & 4 & 2 & 2 \\
Tumor resection & 1 & 0 & 1 \\
Concomitant procedure & & & \\
MAZE & 3 & 2 & 1 \\
TAP & 1 & 1 & 0 \\
\hline
\end{tabular}

There were no significant differences in operative procedures between elective group and urgent group. AVR, aortic valve replacement; MVR, mitral valve replacement; MVP, mitral valvoplasty ; $\mathrm{CABG}$, coronary artery bypass grafting ; TAP, tricuspid annuloplasty.

5.3\%（ $p=0.69 ）$ と有意差は認めなかった。術後入院日数 は $48.5 \pm 58.8$ 日 vs. $28 \pm 46.5$ 日 $(p=0.15)$ と有意差は認 めないものの，挿管時間 $41.7 \pm 47.4$ 時間 vs. $8.2 \pm 3.8$ 時間 $(p=0.003)$ と ICU 滞在期間 $4.0 \pm 3.97$ 日 vs. $1.05 \pm 0.23$ 日 $(p=0.001)$ は緊急手術症例群が延長した。大血管症例を 除いても同様な結果が得られた。

術後合併症として, 新規透析導入は 2 例, 縦隔洞炎 1 例，気管切開を要する長期呼吸不全 2 例，ペースメーカー 
Table 3 Operative data and clinical outcomes

\begin{tabular}{|c|c|c|c|c|}
\hline & $\begin{array}{c}\text { Total } \\
(n=39)\end{array}$ & $\begin{array}{l}\text { Elective } \\
(n=20)\end{array}$ & $\begin{array}{l}\text { Urgent } \\
(n=19)\end{array}$ & $p$-Value \\
\hline \multicolumn{5}{|l|}{ Intra operative variables } \\
\hline Operation time $(\mathrm{min})$ & $305.8 \pm 113.8$ & $272.6 \pm 81$ & $340.9 \pm 136.4$ & 0.03 \\
\hline CPB time (min) & $155.6 \pm 64.7$ & $136.7 \pm 35$ & $174.4 \pm 82.9$ & 0.04 \\
\hline \multicolumn{5}{|l|}{ Postoperative outcomes } \\
\hline Ventilator time $(\mathrm{h})$ & $49.1 \pm 102$ & $8.2 \pm 3.7$ & $89.9 \pm 133.9$ & 0.006 \\
\hline ICU stay（days） & $3.82 \pm 6.5$ & $1.05 \pm 0.2$ & $6.74 \pm 8.5$ & 0.002 \\
\hline Postoperative stay (days) & $41.3 \pm 58.2$ & $27.5 \pm 45.3$ & $58.9 \pm 68$ & 0.049 \\
\hline 30-day mortality (\%) & $2.6(1 / 39)$ & $0(0 / 20)$ & $5.3(1 / 19)$ & 0.3 \\
\hline Hospital mortality $(\%)$ & $15.4(6 / 39)$ & $5(1 / 20)$ & $26.3(5 / 19)$ & 0.065 \\
\hline \multicolumn{5}{|l|}{ State type at 30 days } \\
\hline Home & 18 & 14 & 4 & \\
\hline Other hospital & 6 & 3 & 3 & \\
\hline Our hospital & 14 & 3 & 11 & \\
\hline \multicolumn{5}{|l|}{ Postoperative complications } \\
\hline Renal failure (creatinine $>2.0 \mathrm{mg} / \mathrm{dl})$ & 9 & 2 & 7 & 0.047 \\
\hline Newly dialysis required & 2 & 0 & 2 & 0.14 \\
\hline Mediastinitis & 1 & 1 & 0 & 0.32 \\
\hline Prolonged ventilation $(>72 \mathrm{~h})$ & 8 & 0 & 8 & 0.001 \\
\hline Tracheotomy & 2 & 0 & 2 & 0.14 \\
\hline Pacemaker implantation & 2 & 0 & 2 & 0.14 \\
\hline Cerevrovascular disease & 2 & 0 & 2 & 0.14 \\
\hline Chylothorax & 1 & 0 & 1 & 0.3 \\
\hline NOMI & 1 & 0 & 1 & 0.3 \\
\hline Cholecystitis & 1 & 0 & 1 & 0.3 \\
\hline
\end{tabular}

$\mathrm{CPB}$, cardiopulmonary bypass ; ICU, intensive care unit ; NOMI, nonocclusive mesenteric ischemia.

Table 4 Fatal cases

\begin{tabular}{lllclc}
\hline Age, gender & Diagnosis & Emergency & $\begin{array}{l}\text { Operation } \\
\text { procedure }\end{array}$ & \multicolumn{1}{c}{ Cause of death } & $\begin{array}{c}\text { Postoperative } \\
\text { days }\end{array}$ \\
\hline $\begin{array}{l}\text { 85, male } \\
\text { 85, female }\end{array}$ & TAA rupture & $\begin{array}{l}\text { Urgent } \\
\text { Elective }\end{array}$ & $\begin{array}{l}\text { DAR } \\
\text { AVR }\end{array}$ & $\begin{array}{l}\text { Bleeding } \\
\text { NOMI } \\
\text { Gastrointestinal perforation }\end{array}$ & 1 \\
86, female & AAD & Urgent & AAR & $\begin{array}{l}\text { Lung cancer } \\
\text { Cerebral infarction } \\
\text { Cholecystitis }\end{array}$ & 51 \\
85, male & CAD & Urgent & CABG3 & $\begin{array}{l}\text { Gastrointestinal perforation } \\
\text { AMI }\end{array}$ & 61 \\
88, female & AAD & Urgent & AAR & Takotsubo cardiomyopathy & 62 \\
86, female & TAA rupture & Urgent & TAR & Tak \\
\hline
\end{tabular}

TAA, thoracic aortic aneurysm ; AS, aortic valve stenosis ; AAD, acute aortic dissection ; CAD, coronary artery disease;DAR, descending aorta replacement;AVR, aortic valve replacement;AAR, ascending aorta replacement;CABG, coronary artery bypass grafting;TAR, total arch replacement; NOMI, nonocclusive mesenteric ischemia ; AMI, acute myocardial infarction.

植込み 2 例，脳血管障害 2 例，乳び胸 1 例，非閉塞性腸間 膜動脈虚血（NOMI : nonocclusive mesenteric ischemia） 1 例であった。長期人工呼吸器管理（72 時間以上）を要し た患者数および術後一過性の腎機能障害 (Cre $>2 \mathrm{mg} / \mathrm{dl}$ ) は緊急手術症例に多かったが, 術後新規透析導入やその他 合併症に有意差は認めなかった（Table 3).

術後 30 日死亡は 1 例 $(2.6 \%)$, 入院死亡は 6 例 (12.8\%) であった，死亡症例の詳細を Table 4 に示す。手術関連死 亡は TAA 破裂に対する下行大動脈人工血管置換術の出血
死，AS に対する AVR 後の NOMI による消化管穿孔の 2 症例であり，その他は経過中に発症した急性心筋梗塞，肺 がん化学療法中に AAD が発症し，術後脳転移による脳梗 塞，胆のう炎による消化管穿孔，タコつぼ型心筋症既往の 心不全により失った。

84 歳以下の対象群との比較を Table 5 に示す。若年者群 の主たる基礎疾患は CAD 422 例 (44.9\%), 弁疾患 330 例 (35.1\%)，大動脈疾患 136 例 (14.5\%)，その他 52 例 (5.5\%) であり，高齢者群と比べ手術内容に差は認めなかった。高 
Table 5 Patient's profiles and clinical outcomes

\begin{tabular}{lccc}
\hline & Elderly patients group & Control group & $p$-Value \\
\hline Number & 39 & 940 & \\
Urgent & $19(46.2 \%)$ & $256(27.5 \%)$ & $<0.003$ \\
Age (years) & $86.3 \pm 1.3$ & $67.5 \pm 10.7$ & $<0.001$ \\
Ventilator time (h) & $49.1 \pm 102$ & $52.6 \pm 173.5$ & 0.45 \\
ICU stay (days) & $3.82 \pm 6.5$ & $3.21 \pm 4.3$ & 0.8 \\
Postoperative stay (days) & $41.3 \pm 58.2$ & $30.1 \pm 37.8$ & 0.96 \\
30-day mortality (\%) & $2.6(1 / 39)$ & $3.3(31 / 940)$ & 0.8 \\
Hospital mortality (\%) & $15.4(6 / 39)$ & $4.8(45 / 940)$ & 0.003 \\
\hline
\end{tabular}

ICU, intensive care unit.
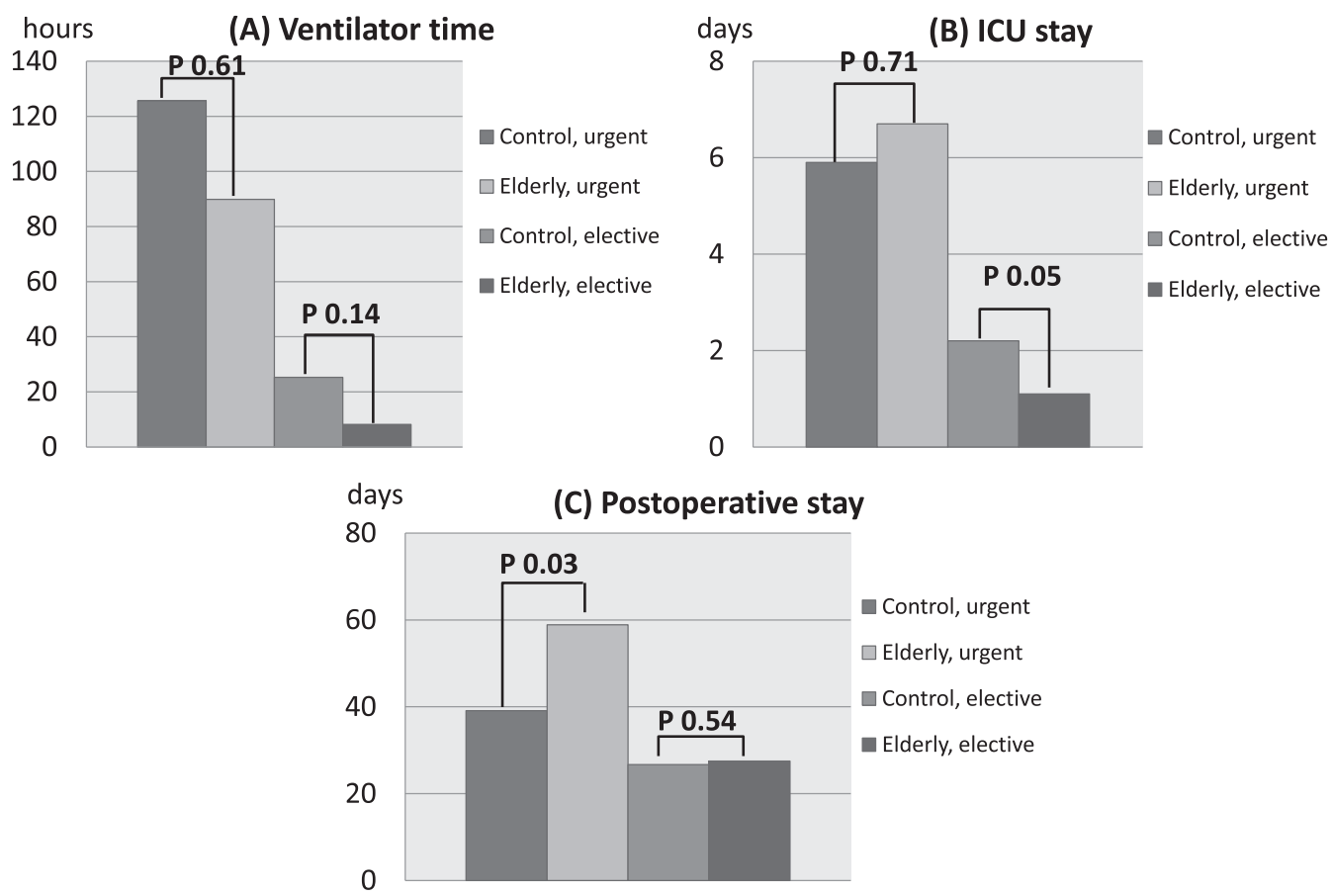

Fig. 1

(A) Ventilator time. In urgent situation, there was no significant difference between control group and elderly group ( $125.6 \pm 300 \mathrm{~h}$ vs. $89.9 \pm 133.9 \mathrm{~h}, p=0.61)$. In elective situation, there was no significant difference in two groups too $(25.3 \pm 69.3 \mathrm{~h}$ vs. $8.2 \pm 3.7 \mathrm{~h}, p=0.61)$. (B) ICU stay. In urgent situation, there was no significant difference between control group and elderly group (5.9 \pm 5.6 days vs. $6.7 \pm 8.5$ days, $p=0.71)$. In elective situation, there was no significant difference in two groups too ( $2.2 \pm 3.2$ days vs. $1.05 \pm 0.2$ days, $p=0.05)$. (C) Postoperative stay. In urgent situation, elderly group had significantly prolonged hospital stay $(58.9 \pm 68$ days vs. $39.1 \pm 34.9$ days, $p=0.03)$. In elective situation, there was no significant difference between control group and elderly group $(26.7 \pm 38.3$ days vs. $27.5 \pm 45.3$ days, $p=0.54)$.

齢者群は対象群と比べ緊急率が高く (46.2\% vs. 27.5\%, $p<0.003)$, 在院死亡率が有意に高かった（15.4\% vs. $4.8 \%, p=0.003)$. 両群間における緊急手術症例と待機手 術症例の術後経過をそれぞれ比較した（Figs. 1，2）。高齢 者の待機手術症例は, 84 歳以下の対象群の待機手術症例 と比べ在院死亡率 $(2.6 \%$ vs. $5.0 \%, p=0.52)$, 術後在院日 数（26.7 238.3 日 vs. $27.5 \pm 45.3$ 日， $p=0.54 ）$ などの術後 経過に有意な差は認めなかった。高齢者の緊急手術症例
は，対象群と比べ術後在院日数が有意に延長し（58.9 \pm 68 日 vs. 39.1 \pm 34.9 日， $p=0.03)$ ，在院死亡率も高かった $(26.3 \%$ vs. $10.5 \%, p=0.004)$.

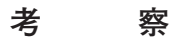

当センターでは年齢にかかわらず， $\mathrm{ADL}$ の自立が得ら れている患者に対しては積極的に手術を行っている.

1990 年代の高齢者に対する心臓手術は high risk とされ 

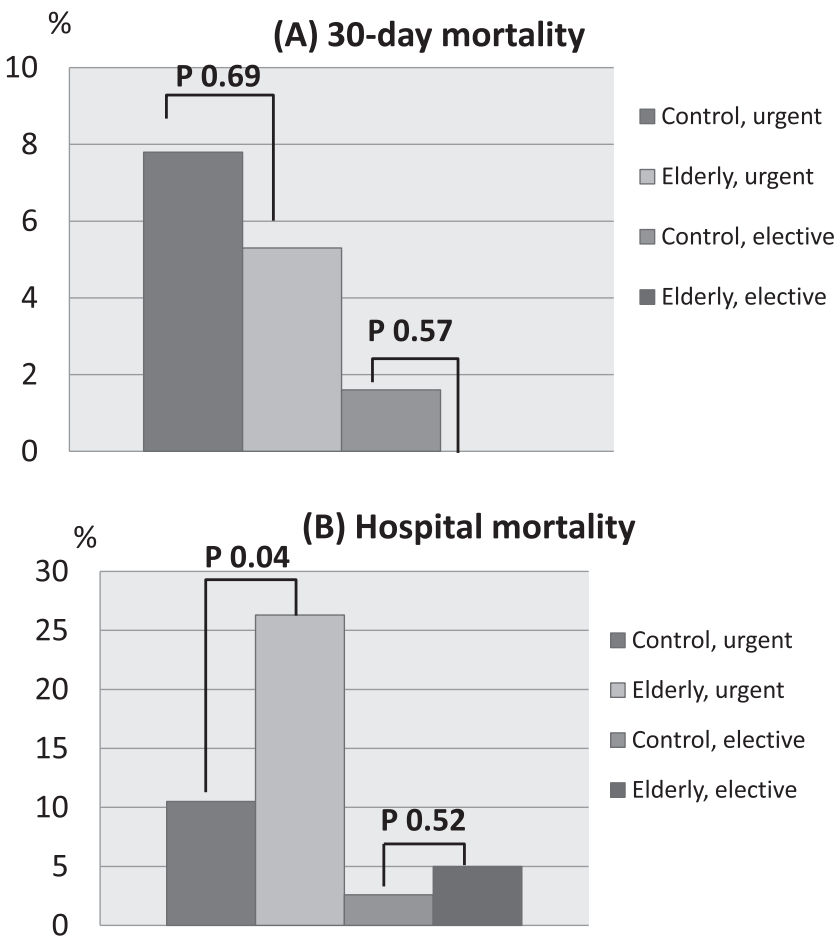

Fig. 2

(A) Thirty-day mortality. In urgent situation, there was no significant difference between control group and elderly group $(7.8 \%$ vs. $5.3, p=0.69)$. In elective situation, there was no significant difference in two groups too $(1.6 \%$ vs. $0 \% p=0.57)$. (B) Hospital mortality. In urgent situation, elderly group had significantly greater hospital mortality than control group $(26.3 \%$ vs. $10.5 \%, p=0.04)$. In elective situation, there was no significant difference between control group and elderly group (2.6\% vs. $5.0 \%, p=0.52)$.

てきたが，85歳以上の超高齢者に対する心臟手術の成績 はいくつか報告されている ${ }^{1 \sim 3)}$. Johnson らは 1993 年から 2001 年までの CABG 症例において 80 歳以上の高齢者は 手術死亡，長期入院，神経学的合併症の危険因子であると 報告している ${ }^{4)}$. 2000 年代になり徐々に手術成績は向上し た. Maganti らは 80 歳以上高齢者の CABGにおいて, 1990 年から 1994 年までの期間に打ける死亡率 7.1\%に対 して，2000 年から 2005 年までの期間の死亡率は $3.2 \%$ と 有意に改善されたとし ${ }^{5}$, Yanagawa らも同様に 1990 年か ら 1996 年までの期間中の死亡率は $6.1 \%$ であったが，2004 年から 2010 年までの期間中の死亡は認めず， 80 歳以上の 高齢は手術死亡の危険因子とならないとしている ${ }^{6}$.われ われの経験においても AVR 同時手術を含めた CABG 13 例 中， 61 日後に胆のう炎からの消化管穿孔による敗血症に て 1 例を失ったが 30 日以内死亡は認めなかった。

高齢者の場合，心臟手術後に長期臥床や合併症などによ り ADL が低下し，時には術前より QOL が低下すること がある. Krane らは緊急手術を含む CABG およびAVRを
施行した 80 歳以上の患者に 36-Item Short Form Health Survey（SF-36）のアンケート行いQOLを検討した結果， 年齢・性別をマッチングした健常人と比べ mental health score は同等であり, physical health score はむしろ手術患 者のほうが高いと報告している7). Ghanta らは開心術後 高齢者の生存率と QOL を検討し，マッチングした健常人 と比べ 5 年打よび 10 年生存率は変わらず mental health score は有意に高かったとし ${ }^{8)}$, Kurlansky らも同様な報告 をしている ${ }^{9)}$. 80 歳以上高齢者の心蔵手術後中期成績は良 好であり，健常人と比べ同等以上の QOL を確立してい る.

今回の検討では, 85 歳以上高齢者の手術では $\mathrm{AAD}$ や TAA 破裂といった大血管緊急手術症例も少なくない.Piccardo らは 80 歳以上高齢者の $\mathrm{AAD}$ 症例の在院死亡率は $45.6 \%$ と高く, 術前循環不全, 神経学的欠損や腎不全を合 併している場合は上行置換術など最小限の手術にとどめ, 保存的療法も考慮すべきとしているが，退院患者における 1 年生存率 $93 \%, 5$ 年生存率 $80 \%$ と良好であると報告して いる ${ }^{10)}$. Vanhuyse らも手術死亡率は $40 \%$ と高いが，その 後の生存率は若年者と比べ有意差はないとし ${ }^{11)}$, Tang ら は 80 歳以上の $\mathrm{AAD}$ 症例 21 人中, 最長 59 力月の観察期 間内で在院死亡，遠隔死亡ともに認めず良好な成績であ り，その後のアンケートで SF-36 は若年者群と比べ有意に 高かったとしている ${ }^{12)}$. Minatoya らはAAD を含めた 80 歳以上高齢者に対する弓部全置換術の在院死亡率は $7.9 \%$ と満足いくものであり, 慢性閉塞性肺疾患は在院死亡の危 険因子とされるが，緊急手術は在院死亡や脳卒中の危険因 子とはならないとしている ${ }^{13)}$ 。さらには，1 年生存率 $84.8 \%, 5$ 年生存率 $58.1 \%$ と良好であり, 高齢だけを理由に 手術不適応とすべきでないとしている. 今回われわれの経 験においても大血管症例 9 例中 4 例を失っているが，手術 関連死亡は TAA 破裂による出血死 1 例のみであり, 過去 の報告と同等の成績であった。

緊急手術症例に大血管手術が多く，その結果手術時間が 延長したものと考えるが，大血管症例を除いた検討でも同 様な結果が得られた。緊急手術症例は待機手術症例に比べ 術後挿管時間，ICU 滞在期間が延長し，死亡率に有意差 がないものの経過中の合併症により入院期間が延長してい る.さらには 30 日以内の自宅退院が 4 人 (21.1\%) と少な かった. 84 歳以下対象群の緊急手術症例と比べても, 術 後挿管時間，ICU 滞在期間，30 日以内の手術死亡率は有 意差がないものの術後入院日数は延長し, 在院死亡率は有 意に高かった。一方で高齢者の待機手術症例では 14 人 (70\%) が 30 日以内に自宅退院し，術後経過においても 84 歳以下の対象群と有意差は認めず満足いく結果であった。

30 日以内に自宅退院された 18 人 $(46.2 \%)$ の退院時に 
おける ADLは良好に保たれており, 最終的に自宅退院し た 24 人 (61.5\%) はすべて独歩退院が可能であった. 術後 合併症により長期入院を余儀なくされた症例やリハビリ目 的に転院された症例の ADL 評価にたいしては，退院後の 生存率を含め今後追跡調査が必要と考える.

古川らは 85 歳以上超高齢者に対して, 心臟手術後 ICU にて人工呼吸器離脱後, 可能な限りベッドサイドより心蔵 リハビリを開始し，かつ術前より家族と他種医療スタッフ が包括的に患者にアプローチすることが重要であり, 術後 の合併症および遠隔期の予後に寄与するものとしてい る ${ }^{14)}$. また, Nakamura らは弁疾患手術後の 80 歳以上高 齢者に対して早期リハビリテーション介入することによ り，術後せん妄を軽減し自宅退院数を増やしたとしてい る ${ }^{15)}$. 当センターでは ICU から一般病棟転出後早期より 循環器内科打よび所属理学療法士により心臟リハビリテー ション介入しているが, 術前からの患者介入や人工呼吸器 離脱後 ICU 内でのリハビリテーションまでは至っていな い. 術前の frailty の把握やさらなる術後早期からのリハビ リテーション介入を行うことにより, 術後入院期間短縮, 合併症の軽減を図る必要があると考えられた。

また，自験例に打いて 5 人が過去に高齢を理由に心臓手 術を拒否し，そのうち 3 人が緊急手術に至った（CABG 2 例, AVR 1 例)。なかには心臓手術に対する十分な説明が なされず，主治医が高齢だけを理由に専門医受診さえされ ていないケースもあった。急性大動脈解離は予見が困難で あるが, 狭心症や弁膜症, 真性大動脈瘤に関しては, 発作 や破裂など患者の病態が重篤化する前に心臓外科受診が可 能である. われわれ外科医は循環器内科や近隣の開業医に 対して, 心臟手術の安全性や現状を説き, 高齢化社会にお ける地域医療に貢献すべきである。

\section{結語}

85 歳以上超高齢者の心臟大血管手術は術後経過におい て全身合併症に十分注意が必要であるが, 手術成績, 術後 経過ともに打打むね良好である，とくに待機手術症例では 若年者と同等な手術成績が見込める. 高齢を理由に手術不 適応と判断するのは早計であり, 患者の frailty や精神状 態，病態の深刻性，患者家族の意思を考慮したうえで手術 適応を判断すべきである。

\section{文献}

1) Levin, I.L., Olivecrona, G.K., Thulin, L.I. et al. : Aortic valve replacement in patients older than 85 years : outcomes and the effect on their quality of life. Coron. Artery Dis. 9 : 373380, 1998.

2) Rosengart, T.K., Finin, E.B., Kim, D.Y. et al. : Open heart surgery in the elderly : results from a consecutive series of 100 patients aged 85 years or older. Am. J. Med. 112 : 143147, 2002.

3) Davis, W.J. 3rd, Vaynblat, M., Chiavarelli, M. et al. : Open heart surgery in patients 85 years and older. J. Card. Surg. $19: 7-11,2004$

4) Johnson, W.M., Smith, J.M., Woods, S.E. et al. : Cardiac surgery in octogenarians: does age alone influence outcomes ?. Arch. Surg. 140 : 1089-1093, 2005.

5) Maganti, M., Rao, V., Brister, S. et al. : Decreasing mortality for coronary artery bypass surgery in octogenarians. Can. J. Cardiol. 25 : e32-e35, 2009.

6) Yanagawa, B., Algarni, K.D., Yau, T.M. et al. : Improving results for coronary artery bypass graft surgery in elderly. Eur. J. Cardiothorac. Surg. 42 : 507-512, 2012.

7) Krane, T., Voss, B., Hiebinger, A. et al. : Twenty years of cardiac surgery in patients aged 80 years and older : risk and benefits. Ann. Thorac. Surg. 91 : 506-513, 2011.

8) Ghanta, R.K., Shekar, P.M., McGurk, S. et al. : Long-term survival and quality of life justify cardiac surgery in the very elderly patient. Ann. Thorac. Surg. 92 : 851-857, 2011.

9) Kurlansky, P.A., Williams, D.B., Traad, E.A. et al. : Eighteenyear follow-up demonstrates prolonged survival and enhanced quality of life for octogenarians after coronary artery bypass grafting. J. Thorac. Cardiovasc. Surg. 141 : 394-399, 2011.

10) Piccardo, A., Regesta, T., Zannis, K. et al. : Outcomes after surgical treatment for type A acute dissection in octogenarians : multicenter study. Ann. Thorac. Surg. 88: 491-497, 2009.

11) Vanhuyse, F., Maureira, P., Laurent, N. et al. : Surgery for acute type A aortic dissection in octogenarians. J. Card. Surg. $27:$ 65-69, 2012.

12) Tang, G.H.L., Malekan, R., Yu, C.J. et al. : Surgery for acute type A dissection in octogenarians is justified. J. Thorac. Cardiovasc. Surg. 145 : S186-S190, 2013.

13) Minatoya, K., Ogino, H., Matsuda, H. et al. : Is conventional aortic arch surgery justifiable in octogenarians?. J. Thorac. Cardiovasc. Surg. 139 : 641-645, 2010.

14) Furukawa, H., Kangai, K., Minami, K. et al. : Initial clinical experience of early cardiac rehabilitation for very elderly patients over 85 years old following open heart surgery. Kyobugeka 65 : 440-445, 2012.

15) Nakamura, K., Nakamura, E., Niina, K. et al. : Outcome after valve surgery in octogenarians and efficacy of early mobilization with early cardiac rehabilitation. Gen. Thorac. Cardiovasc. Surg. 58 : 606-611, 2010. 